\title{
Świat kultury materialnej na magnackim dworze na przykładzie rejestrów majątkowych Anny Katarzyny z Sanguszków Radziwiłłowej z lat 1738-1741
}

\begin{abstract}
Abstrakt: Celem artykułu jest analiza rejestrów majątku kanclerzyny litewskiej Anny Katarzyny z Sanguszków Radziwiłłowej, rozpoznanie rytmu funkcjonowania jej dworu, w tym odróżnienie spraw codziennych od różnych przejawów przepychu i luksusu. Podstawą są rozmaite rejestry majątkowe kanclerzyny. Analizowane materiały z lat 1738-1741 dotyczą przede wszystkim specyfiki funkcjonowania dworu bialskiego. Bazę źródłową uzupełniają zapiski z prywatnej korespondencji, wskazujące na prywatne upodobania magnatki i sposób pozyskiwania określonych przedmiotów. Wykorzystane rejestry rzeczy ukazane zostały jako cenne źródło do poznania dworskiej codzienności w XVIII stuleciu oraz doskonały materiał do badań wielu zagadnień z ówczesnej sfery materialnej.

Abstract: The aim of the article is to analyse the property inventories of Anna Katarzyna Radziwiłł née Sanguszko, wife to the Lithuanian chancellor. This source material has a considerable value for exploring the rhythm of the court's functioning, including the distinction between everyday matters and various manifestations of splendour and luxury. Various property inventories of the magnate were analysed. The materials used, coming from 1738-1741, mainly concerned the particulars of the functioning of the Biała estate. The source base was supplemented by information from private correspondence, indicating the individual taste of the magnate and her methods of obtaining particular items. Inventories were shown to be a valuable source for research on the everyday life of magnate courts in the 18th century. It is also an excellent material for researching many issues connected with the material sphere and the use of goods in that time.
\end{abstract}

Słowa kluczowe: Radziwiłłowie, kultura materialna, inwentarz, życie codzienne, XVIII wiek

Key words: Radziwiłł family, material culture, inventory, everyday life, 18th century

Specyfika funkcjonowania kobiecych dworów magnackich w XVIII wieku nadal stanowi tematykę rozpoznaną w niewielkim stopniu ${ }^{1}$. Wartościowe źródło do badań tego zagadnienia stanowią zachowane rejestry majątkowe. Pozwalają one rozszerzyć dotychczasowe ustalenia o zagadnienia związane z werbowaniem i utrzymywaniem służby dworskiej, opłacaniem bieżących wydatków związanych z funkcjonowaniem dworu oraz prowadzeniem spraw gospodarczych w majątkach zarządzanych przez kobiety. Umożliwiają one ponadto rozpoznanie rytmu funkcjonowania dworu, w tym odróżnienie spraw codziennych od różnych przejawów przepy-

1 Szerszego opracowania doczekały się dwory wybranych królowych i magnatek, por.: Targosz K. 1975; Targosz K. 1997; Jakuboszczak A. 2008; Markuszewska A. 2012; Słaby A. 2014; Kuras K. 2018; Popiołek B. 2020. 
chu i luksusu. Aktywność Anny Katarzyny z Sanguszków Radziwiłłowej (†1746)², wdowy po kanclerzu wielkim litewskim Karolu Stanisławie Radziwille (†1719), wydaje się w tym kontekście szczególnie interesująca. Dysponująca ogromnym majątkiem magnatka od śmierci męża sterowała zarówno polityczną, jak i majątkową aktywnością domu radziwiłłowskiego ${ }^{3}$. Świadectwem jej działalności jest ogromna spuścizna źródłowa, na którą składają się przede wszystkim obszerne akta majątkowe i rozległa korespondencja. Liczne rejestry mobiliów kanclerzyny stanowiły już podstawę najobszerniejszej dotąd publikacji poświęconej życiu księżnej — biografii autorstwa Wandy Karkucińskiej, wydanej w 2000 r. ${ }^{4}$

Dla zobrazowania specyfiki funkcjonowania dworu Radziwiłłowej w prezentowanym artykule sięgnięto również po rozmaite rejestry majątkowe kanclerzyny. Analizowane materiały z lat 1738-1741, dotyczące specyfiki funkcjonowania dworu bialskiego, nie zostały wykorzystane przez autorkę biografii Anny Katarzyny ${ }^{5}$. Tymczasem ta dokumentacja pozwala na rozpatrywanie dworskiej codzienności w wielu aspektach ${ }^{6}$. Rejestrowaniu podlegały bowiem zarówno produkty żywnościowe, jak i przedmioty użytkowe - meble, materiały, zastawa stołowa, karoce i powozy, drobne kosztowności, a także inwentarzy żywy. Analiza została rozszerzona również o zapiski z prywatnej korespondencji księżnej. Dopiero tak dobrany zasób materiałów pozwala formułować wnioski co do gustów i upodobań kanclerzyny, zestawu przedmiotów, jakimi się otaczała, a także motywów zakupu specyficznych mobiliów. Na tej podstawie możliwe jest też rozróżnienie wyrobów i towarów używanych na co dzień na magnackim dworze, od tych, przeznaczonych wyłącznie na szczególne okazje.

Dobór archiwaliów z lat 1738-1741 nie jest przypadkowy. Wykazy ze wskazanego okresu zdają się być miarodajnym źródłem oddającym zwyczajny rytm funkcjonowania dworu. W latach 1733-1735 dobra Radziwiłłowej mocno ucierpiały w skutek działań wojsk podczas walk o koronę polską pomiędzy zwolennikami elektora saskiego Fryderyka Augusta II (†1763) i Stanisława Leszczyńskiego $(\dagger 1766)^{8}$. Kanclerzyna w swej korespondencji z tego okresu wielokrotnie uskarżała się na rabunki w jej dobrach, a także na swawolne bandy, bez umiaru pustoszące radziwiłłowskie majętności ${ }^{9}$. W jednym z rozpaczliwych listów do syna, Hieronima Floriana Radziwiłła $(\dagger 1760)^{10}$, księżna raportowała: „trzema traktami przez dobra nasze szli. Jedna jeno partynka ${ }^{11}$ w Mirze przez jeden nocleg półtora tysiąca wozów siana spasła i kilkaset

2 Anna Katarzyna z Sanguszków Radziwiłłowa — córka Hieronima Sanguszki i Konstancji z Sapiehów, żona Karola Stanisława Radziwiłła. Wraz z mężem doczekała się licznego potomstwa — synów: Mikołaja Krzysztofa, Mikołaja Kazimierza, Hieronima Floriana, i córek: Tekli Róży (żony kolejno Jakuba Flemminga, Michała Serwacego Wiśniowieckiego i Michała Antoniego Sapiehy), Katarzyny Barbary (żony Jana Klemensa Branickiego), Konstancji Franciszki (żony Jana Fryderyka Sapiehy) i Karoliny Teresy (żony Kazimierza Leona Sapiehy, a następnie Józefa Aleksandra Jabłonowskiego). Owdowiała w 1719 r. i od tego czasu aktywnie angażowała się w politykę domu radziwiłłowskiego, stając się główną autorką działań politycznych, ekonomicznych, a także inicjatorką polityki matrymonialnej swoich dzieci.

3 Anusik Z., Stroynowski A. 1989, s. 37; Popiołek B. 2020, s. 381-414.

${ }^{4}$ Karkucińska W. 2000.

${ }^{5}$ AGAD, AR, dz. XXIX, rkps 29.

${ }^{6}$ Penkała-Jastrzębska A. 2021.

7 Więcej o zagadnieniu prestiżu i luksusu w odniesieniu do przedmiotów kultury materialnej w szlacheckich inwentarzach, zob.: Dumanowski J. 2006, s. 82; Roćko A. 2013, s. 11-22; Kicińska U. 2017, s. 461-470; Penkała-Jastrzębska A. 2020, s. 33-62.

${ }^{8}$ Zob.: Codzienne kłopoty. 2013, szczególnie wstęp.

9 AGAD, AR, dz. IV, nr 623, s. 102-250.

${ }^{10}$ Hieronim Florian Radziwiłł — starosta przemyski, krzyczewski, podczaszy wielki litewski i (od 1750 r.) chorąży wielki litewski. Trzykrotnie żonaty — z Teresą z Sapiehów, Magdaleną z Czapskich i Anielą z Miączyńskich. Znany ze swej porywczości i skłonności do używek, zob.: Dymnicka-Wołoszyńska H. 1980, s. 188; Sajkowski A. 1981; Maciejewska I., Zawilska K. 2015, s. 263-271; Listy Magdaleny z Czapskich. 2016.

11 Partynka - część, grupa. 
beczek owsa i tak trzema kolumnami szli. Jedna na Kopyś, druga na Nieśwież, trzecia na Mir”12. To zaś generowało straty, które kanclerzyna usiłowała sobie powetować po zakończeniu konfliktu elekcyjnego. Koniec lat czterdziestych na powrót przyniósł stabilizację, zaś bialski dwór Anny Katarzyny wrócił do normalnego trybu funkcjonowania.

Rozróżnienie produktów codziennego zastosowania od tych, przeznaczonych wyłącznie na wyjątkowe okazje doskonale obrazuje zestawienie towarów używanych w magnackiej kuchni. Część potraw serwowana była regularnie, inne zaś sporadycznie, od święta. Do pierwszej grupy można zaliczyć ryby. W rejestrach najczęściej wzmiankowano wędzone (szczupaki) i marynowane $\left(\right.$ sielawy $^{13}$, jesiotry ${ }^{14}$ ), a także sztokfisz, czyli ryby suszone ${ }^{15}$. Swoje ulubione produkty żywnościowe Anna Katarzyna nierzadko zamawiała osobiście. Życzyła sobie np. żeby z Królewca przesyłać beczki „śledzi dobrych olęderskich”"16 i innych podobnych specjałów ${ }^{17}$. Na podstawie korespondencji Radziwiłłowej można wnioskować, że zapasy ryb trafiały do jej siedziby zwłaszcza w tygodniach poprzedzających Wielkanoc. Zamawiano je wówczas razem z transportem „innych rzeczy na post”18. W pozostałych okresach roku kanclerzynie częściej serwowano różne wyroby mięsne, jak choćby wędzone szynki ${ }^{19}$ oraz wytwarzane przez służbę kiełbasy ${ }^{20}$. Regularnie w jej menu gościły też ryż i makaron ${ }^{21}$. Wszystkie potrawy dla księżnej przygotowywali zatrudnieni na dworze kucharze. Anna Katarzyna osobiście nadzorowała ich rekrutację, szukając ludzi doświadczonych w swym fachu, lecz nie najdroższych w utrzymaniu. W jednym z listów do syna pisała: „starajcie się po staremu tam o kucharzów dobrych, tylko nie w Mannheimie, bo tam wszyscy bardzo drodzy, ale jak się książęta zjadą niemieccy, przy których zawsze Niemcy są dobrzy”22.

Generalnie kanclerzyna przykładała dużą wagę do tego, co podawano na jej stół. Widoczne jest jej zaangażowanie w tę kwestię, co wyróżniało ją spośród innych członków rodziny, o czym wspominała w jednym z listów do syna, Michała Kazimierza Radziwiłła $(\dagger 1762)^{23}$ : „ty zaś moje dziecię w tym podobny jesteś do ojca swego, który byle dla siebie jedną potrawę miał na stole dobrą, nie dbał o więcej, ja zaś o to z kuchmistrzami kłóciłam się żeby wszystko było dobrze póty, aż przyprowadziłam do porządku należytego"24. Brak dbałości o kulturę stołu i obojętność względem jakości serwowanego pożywienia magnatka poczytywała za niekwe-

12 AGAD, AR IV, nr 623, „Anna Katarzyna z Sanguszków Radziwiłłowa do Hieronima Floriana Radziwiłła, Gdańsk, 14 XI 1733”, s. 132.

13 AGAD, AR, dz. XXIX, rkps 29, s. 210.

14 AGAD, AR, dz. XXIX, rkps 29, s. 236.

15 AGAD, AR, dz. XXIX, rkps 29, s. 48.

${ }^{16}$ Leszek Jasielczuk, analizując zakonne rejestry majątkowe, interpretował sprowadzane do kuchni śledzie olęderskie jako śledzie holenderskie, zob.: Jasielczuk L. 2005, s. 80.

17 AGAD, AR IV, nr 624, „Anna Katarzyna z Sanguszków Radziwiłłowa do Adolfa Saturgusa”, Biała, 2 XI 1735, s. 233.

18 AGAD, AR IV, rkps 630, „Anna Katarzyna z Sanguszków Radziwiłłowa do Michała Kazimierza Radziwiłła, Biała 16 III 1745”, s. 141.

19 AGAD, AR, dz. XXIX, rkps 29, s. 142.

${ }^{20}$ AGAD, AR, dz. XXIX, rkps 29, s. 164.

21 AGAD, AR, dz. XXIX, rkps 29, s. 49.

22 AGAD, AR IV, nr 624, „Anna Katarzyna z Sanguszków Radziwiłłowa do Michała Kazimierza Radziwiłła, Biała, 1 XII 1734”, s. 69.

${ }^{23}$ Michał Kazimierz Radziwiłł — syn Karola Stanisława Radziwiłła i Anny z Sanguszków Radziwiłłowej, hetman wielki litewski, wojewoda wileński, po śmierci starszego brata Mikołaja Krzysztofa jako najstarszy z rodzeństwa miał odziedziczyć po rodzicach największą część dóbr radziwiłłowskich, Dymnicka-Wołoszyńska H. 1987, s. 299; Zielińska T. 1989; Pietrzak J. 2016, s. 99-131; Zuba K. 2002, s. 53-84.

${ }^{24}$ AGAD, AR IV, nr 629, „Anna Katarzyna z Sanguszków Radziwiłłowa do Michała Kazimierza Radziwiłła, Biała, 13 V 1742”, s. 176. 
stionowaną wadę charakteru syna. Nie może zatem dziwić, że w analizowanych źródłach regularnie pojawiały się też zapisy potwierdzające przygotowywanie różnorodnych przysmaków specjalnie na jej potrzeby i dokładnie zgodne z jej gustem.

Anna Katarzyna utrzymywała m.in. przynamniej kilku cukierników, chętnie też polecała ich usługi najbliższym. Jednego z nich rekomendowała np. Michałowi Kazimierzowi, zapewniając, że w razie potrzeby „nie było [by go — A.P.-J.] trudno posłać”25. Zdaje się jednak, że usługi tych specjalistów na innych dworach nie były już wtedy tak potrzebne, gdyż — jak księżna sama pisała - „teraz panowie nasi polscy absolute cukierników nie zażywają”26. Radziwiłłowa kierowała się jednak w tym względzie osobistymi upodobaniami. Zatrudnieni na bialskim dworze mistrzowie przygotowywali dla niej różne specjały, m.in. słodkie biszkopty ${ }^{27}$, a także porcje cukierków $^{28}$. Do ich wykonania otrzymywali systematycznie dodatkowy przydział cukru ${ }^{29}$.

O regularne sprowadzanie tego ostatniego produktu do Białej kanclerzyna zabiegała, wymieniając go wśród innych, bieżących potrzeb. Zgodnie z jej życzeniem, z Zabłudowa przywożono do Białej zapas „,cukru kanaru ${ }^{30 ” ~ i ~ „, c u k r u ~ m e l i s u ~}{ }^{31}$ dobrego w małych głowach”32. Rejestry potwierdzają, że wydzielano też porcję cukru „na galarety” na magnacki stół ${ }^{33}$. Cukiernik był jednocześnie odpowiedzialny za przesmażenie: fiołkó $w^{34}$, całych pomarańczy ${ }^{35}$ i ich kwiató $w^{36}$, cytryn $^{37}$, agrestu ${ }^{38}$, poziomek ${ }^{39}$, porzeczek ${ }^{40}$, malin ${ }^{41}$ oraz śliwek $^{42}$ serwowanych w formie słodkiego poczęstunku. Stosunkowo rzadko w spisach są wzmianki o wypiekaniu dla księżnej kołaczy ${ }^{43}$ lub przyrządzaniu marcepanu ${ }^{44}$.

Na stole magnatki sporadycznie pojawiały się też egzotyczne owoce, takie jak figi i rodzynki tureckie. W tych przypadkach zawsze dopisywano, że zostały wydane wyłącznie „do rąk Księżnej”45. Anna Katarzyna regularnie otrzymywała też różne produkty od swoich dzieci. Michałowi Kazimierzowi dziękowała choćby za przysłanie zapasu gruszek chwaląc, że były „bardzo dobre” ${ }^{46}$. Z warzyw najczęściej serwowano dla niej sałatę, świeże ogórki ${ }^{47}$, a także różnorodne przetwory ${ }^{48}$.

25 AGAD, AR IV, nr 627, „Anna Katarzyna z Sanguszków Radziwiłłowa do Michała Kazimierza Radziwiłła, Biała, 16 I 1739”, s. 20.

${ }^{26}$ AGAD, AR IV, nr 627, „Anna Katarzyna z Sanguszków Radziwiłłowa do Michała Kazimierza Radziwiłła, Biała, 16 I 1739”, s. 20.

27 AGAD, AR, dz. XXIX, rkps 29, s. 49.

${ }^{28}$ AGAD, AR, dz. XXIX, rkps 29, s. 256.

${ }^{29}$ AGAD, AR, dz. XXIX, rkps 29, s. 66.

${ }^{30}$ Cukier kanar - potoczne określenie cukru trzcinowego, zob.: Gloger Z. 1902, s. 321-322.

31 Cukier melis - określenie cukru białego, zob.: Przyrembel Z. 1927, s. 8.

32 AGAD, AR IV, nr 629, „Anna Katarzyna z Sanguszków Radziwiłłowa do Adolfa Saturgusa”, Biała, 2 VI 1742, s. 284.

${ }^{33}$ AGAD, AR, dz. XXIX, rkps 29, s. 68.

${ }^{34}$ AGAD, AR, dz. XXIX, rkps 29, s. 265.

35 AGAD, AR, dz. XXIX, rkps 29, s. 87.

36 AGAD, AR, dz. XXIX, rkps 29, s. 115.

${ }^{37}$ AGAD, AR, dz. XXIX, rkps 29, s. 100.

38 AGAD, AR, dz. XXIX, rkps 29, s. 115.

39 AGAD, AR, dz. XXIX, rkps 29, s. 115.

${ }^{40}$ AGAD, AR, dz. XXIX, rkps 29, s. 131.

${ }^{41}$ AGAD, AR, dz. XXIX, rkps 29, s. 131.

42 AGAD, AR, dz. XXIX, rkps 29, s. 147.

${ }^{43}$ AGAD, AR, dz. XXIX, rkps 29, s. 185.

44 AGAD, AR, dz. XXIX, rkps 29, s. 210.

45 AGAD, AR, dz. XXIX, rkps 29, s. 145.

46 AGAD, AR IV, nr 627, „Anna Katarzyna z Sanguszków Radziwiłłowa do Hieronima Floriana Radziwiłła, Biała, 1 X 1739”, s. 176.

${ }^{47}$ AGAD, AR, dz. XXIX, rkps 29, s. 110.

48 AGAD, AR, dz. XXIX, rkps 29, s. 82. 
Do picia zwyczajowo podawano piwo. Do produkcji napoju, który spożywała kanclerzyna, zawsze zużywano dodatkowy przydział ,wielkich rodzynków”49. W rejestrach wspominane są też duże zapasy wina zdeponowanego w dworskich piwnicach ${ }^{50}$. Sama Radziwiłłowa zdecydowanie preferowała właśnie ten trunek, o czym wspominała wielokrotnie w swej korespondencji. Prosiła m.in. by przysyłać jej wyłącznie takie wino, „aby nie było ostre, ale słodkawe”51. Zapasami tego napoju w Białej kanclerzyna obdarowywała też swoje dzieci. Znając zaś upodobania odwiedzających je osób, doradzała np. Hieronimowi Florianowi: „pan starosta Wiłkowski zbiegnie do was do Słucka. Wina węgierskiego wiem, że dla niego potrzeba będzie, wybierz dla niego z win, którem tam posłała [...] wina stołowego antał jutro stąd wyprawię"52.

Równie skrupulatnie wydzielano też przyprawy kupowane na potrzeby dworu. Wśród najczęściej sprowadzanych były: imbir, rodzynki (rozróżniane na wielkie i małe), słodkie migdały, ryż, cynamon, goździki, szafran i gałka muszkatołowa ${ }^{53}$. Dzielono je też pod kątem przeznaczenia — jak choćby rodzynki wielkie i małe „na stół”, od tych przeznaczonych „do piwa”54. Pieprz, imbir, cynamon i goździki na te bezpośrednio do pańskiej kuchni oraz wydawane „do robienia kiełbas" ${ }^{55}$. Cukier, oprócz porcji do przyrządzania ciast i deserów (co wskazano już wcześniej), przekazywano również „do kuchni” i „do cukierniczek do stołu Księżnej”56. Jako dodatku używano też skórek pomarańczowych ${ }^{57}$. Przyprawy miały też inne zastosowanie. Kardamon, sporadycznie pojawiający się w rejestrach, nie był przeznaczony do spożycia, lecz otrzymywał go aptekarz, jako specyfik „do apteki”58. Podobnie działo się z „miodem różowym”59, skutecznym przede wszystkim jako środek na gardło ${ }^{60}$. Na różne potrzeby zużywano też zapas szafranu, którego część trafiała m.in. do tapisiera, „do farbowania nici na żółto”61. Osobno wykazywano też przyprawy tzw. „ordynaryjne”, czyli nieodzowne w kuchni, nieco gorszej jakości. W ten sposób określano chociażby pieprz ${ }^{62}$ potrzebny „do wędzenia szczupaków”63. Natomiast na pańskim stole używano pieprzu „dobrego”. Podobnie imbir, którego część potrzebna była podczas obróbki żywności, np. do „marynowania sielaw”64.

W omawianym czasie możliwości pozyskania niezbędnych na dworze produktów były znacznie większe niż kilka lat wcześniej, o czym już wcześniej wspomniano. W konsekwencji niepokojów politycznych w Rzeczypospolitej po śmierci Augusta II szybko odczuwane były problemy z dostarczaniem na dwór różnych towarów, zarówno tych podstawowych, jak i luksusowych. Szukając wyjścia z tej trudnej sytuacji, Anna Katarzyna polecała, by krewni potrzebne produkty kupowali dla niej w trakcie swoich zagranicznych podróży. Kanclerzyna szczególnie zaangażowała w to wówczas Hieronima Floriana, przybywającego na dworze w Mannheim, podejmującego starania o zawarcie małżeństwa z jedną z wnuczek skoligaconego z Radziwił-

49 AGAD, AR, dz. XXIX, rkps 29, s. 83.

${ }^{50}$ AGAD, AR, dz. XXIX, rkps 29, s. 83

51 AGAD, AR IV, nr 629, „Anna Katarzyna z Sanguszków Radziwiłłowa do Saturgusa, Biała, 28 I 1742 ”, s. 107.

52 AGAD, AR IV, nr 628, „Anna Katarzyna z Sanguszków Radziwiłłowa do Michała Kazimierza Radziwiłła, Niehilewicze, 9 II 1740”, s. 137.

53 AGAD, AR, dz. XXIX, rkps 29, s. 22.

${ }^{54}$ AGAD, AR, dz. XXIX, rkps 29, s. 23.

55 AGAD, AR, dz. XXIX, rkps 29, s. 23.

${ }^{56}$ AGAD, AR, dz. XXIX, rkps 29, s. 87.

57 AGAD, AR, dz. XXIX, rkps 29, s. 82.

58 AGAD, AR, dz. XXIX, rkps 29, s. 83.

59 Zob.: Krótki Z. 2016, s. 89.

${ }^{60}$ AGAD, AR, dz. XXIX, rkps 29, s. 134.

${ }^{61}$ AGAD, AR, dz. XXIX, rkps 29, s. 130.

62 AGAD, AR, dz. XXIX, rkps 29, s. 22.

63 AGAD, AR, dz. XXIX, rkps 29, s. 22.

${ }^{64}$ AGAD, AR, dz. XXIX, rkps 29, s. 50. 
łami elektora Karola III Wittelsbacha. W liście do syna pisała: „przypominam W[asz] M[ości], abyś pamiętał czego w skarbcach moich niedostaje, abyś nakupił tam czego będzie można dostać”65. Księżna chciała, by wracając do Rzeczypospolitej przywiózł jej przede wszystkim cytryny i zapas „kasztanów dobrych”. W tym samym liście kazała mu jednocześnie zaniechać transportu ostryg, „kiedy taka dalej będzie odwilż”66, bojąc się o jakość tego towaru, dostarczonego w niesprzyjających okolicznościach.

Niezależnie od okoliczności politycznych i majątkowych wpisy w rejestrach dowodziły także zapobiegawczości i dbałości o to, aby w gospodarstwie nic się nie marnowało. Stąd pośród wykazu towarów wydawanych kuchmistrzowi i cukiernikowi odnaleźć można np. polecenie przekazania dodatkowych „trzech głów cukru [...] do przesmażenia starych konfitur”67.

Na potrzeby dworu regularnie, co miesiąc, kupowano duży zapas kawy. Tańszy i zapewne nieco gorszy produkt, określany jako „kawa rozchodnia”, trafiał do codziennego spożycia ${ }^{68}$. W wielu przypadkach zaznaczano, że miała ona być zaniesiona prosto do pokoi kanclerzyny ${ }^{69}$. Ten rodzaj kawy był też rozdzielany wśród innych osób — księży i administratorów dóbr. Nabywano też „dobrą kawę" "70, która miał być podawana jedynie w szczególnych okolicznościach — w święta lub podczas wizyt gości.

Tak jak kawę reglamentowano też inne towary specjalnego przeznaczenia, zazwyczaj droższe, których ilość była ograniczona. Dotyczyło to np. „anyżu do cukierni”, wydawanego wyłącznie „pod bytność różnych gości”" Na okoliczność wizyt wybranych osób na dworze kanclerzyny kupowano również niewielki zapas pistacji i „tartofli”72, czyli ziemniaków. Na czas pobytu na dworze w Białej bratanka kanclerzyny, Janusza Aleksandra Sanguszki (†1775), miecznika wielkiego litewskiego, kuchnia otrzymała m.in. dodatkowy przydział cukru, gorzkich i słodkich migdałów, goździków i cynamonu ${ }^{73}$. „Głowę cukru” wydano też w związku z przyjazdem córki Anny Katarzyny, wojewodziny brzeskiej Karoliny Teresy z Radziwiłłów Sapieżyny (†1765), wdowy po Kazimierzu Leonie Sapiesze $(† 1738)^{74}$. Innych gości podejmowano najczęściej specjalnie wypiekanymi na tę okazję biszkoptami ${ }^{75}$. Serwowano też dla nich trunki trzymane na podobne okoliczności. Do rarytasów, bardzo rzadko podawanych na dworze, należała wódka cynamonowa. W rejestrach zaznaczano, że była ona wyłącznie „do częstowania gości”76. Odwiedzający bialski dwór raczyli się również wódką karolkową ${ }^{77}$. Ten alkohol jednak wydawano częściej, także „na drogę” różnym osobom realizującym interesy Radziwiłłowej ${ }^{78}$. W celach reprezentacyjnych, „pod bytność gości”, kupowano też okazjonalnie nieco „szafranu do cukierni”79.

65 AGAD, AR IV, nr 624, „Anna Katarzyna z Sanguszków Radziwiłłowa do Hieronima Floriana Radziwiłła, Biała, 31 I 1735”, s. 105.

${ }^{66}$ AGAD, AR IV, nr 624, „Anna Katarzyna z Sanguszków Radziwiłłowa do Hieronima Floriana Radziwiłła, Biała, 31 I 1735”, s. 105.

${ }^{67}$ AGAD, AR, dz. XXIX, rkps 29, s. 36.

68 AGAD, AR, dz. XXIX, rkps 29, s. 22.

${ }^{69}$ AGAD, AR, dz. XXIX, rkps 29, s. 34.

${ }^{70}$ AGAD, AR, dz. XXIX, rkps 29, s. 22.

71 AGAD, AR, dz. XXIX, rkps 29, s. 22.

72 AGAD, AR, dz. XXIX, rkps 29, s. 86, ziemniaki miały być podawane jako deser; zob.: Tomczak L. 2001 s. 123-124. Jędrzej Kitowicz o zmianach na szlacheckich stołach pisał później: „Pistacje i pinele wyszły z mody, a nastały na ich miejsce kapary, oliwki, serdele, tartofle i ostrygi marynowane”, Kitowicz J. 2003, s. 154.

73 AGAD, AR, dz. XXIX, rkps 29, s. 189.

74 AGAD, AR, dz. XXIX, rkps 29, s. 189.

75 AGAD, AR, dz. XXIX, rkps 29, s. 221.

${ }^{76}$ AGAD, AR, dz. XXIX, rkps 29, s. 199.

77 Wódka karolkowa inaczej kminkówka.

78 AGAD, AR, dz. XXIX, rkps 29, s. 235.

${ }^{79}$ AGAD, AR, dz. XXIX, rkps 29, s. 34. 
Większe ilości rozmaitych produktów spożywczych odnotowywano z okazji świąt. W grudniu 1738 r. porcję słodkich i gorzkich migdałów ${ }^{80}$, wosku i cukru wydzielono cukiernikowi, z przeznaczeniem „na święta dla Ks[iężnej] J[ej] M[ość] Dobr[odziejki]”81. Szczególnie obszerna była lista zakupów dokonywanych przed Wielkanocą. Przede wszystkim sprowadzano wówczas odpowiednio więcej przypraw i korzeni do przygotowania wielu dań: rodzynek, imbiru, cynamonu, cukru i goździków „do nadziewania baranków i prosiąt”, poza tym rodzynki, migdały, cukier i cynamon „do kołacza”, rodzynki migdały, szafran i cukier „do placków słodkich”, oraz dodatkowy zapas pieprzu „do kiełbas”"2 . Taki zestaw artykułów wydano w marcu tegoż roku „na Święta Wielkanocne dla Księżnej”83. Dwa lata później (w 1740 r.) w analogicznym okresie rozdysponowano rodzynki, goździki, cukier, pieprz, imbir, cynamon i miodownik „do nadziewania baranków i prosiąt”84. Zbliżoną listę produktów, złożoną m.in. z rodzynek, migdałów, szafranu i cukru, przeznaczono „do placków” i „do kołacza”85. Zapisy takie, wzbogacane czasem o inne artykuły, np. imbir i cynamon, powtarzały się co roku ${ }^{86}$.

Należytą oprawę nadawano też uroczystościom prywatnym osób związanych z dworem. Pokaźny zestaw przypraw, złożony z cukru, pieprzu, imbiru, cynamonu i migdałów, przeznaczono na przygotowanie smakołyków „na wesele pana Chomińskiego” w 1738 r. Rodzynki, migdały i cukier ofiarowano też cukiernikowi, by wykorzystał je na własne wesele ${ }^{87}$. Słodkie migdały i artykuły „do cukierni” zagwarantowano również w związku z weselem Mogilnickiego, sędziego przemyskiego ${ }^{88}$. Przy tej ostatniej okazji zanotowano, że ze spiżarni kanclerzyny wydano jeszcze kilka innych produktów (migdały, rodzynki i cukier) „do kołacza”, upieczonego na tę właśnie uroczystość. Prywatna korespondencja dowodzi, że Anna Katarzyna traktowała tego rodzaju wydatki raczej jako kłopotliwą powinność. W 1738 r. magnatkę absorbowały bowiem przede wszystkim niezamknięte sprawy finansowe z Sapiehami, dotyczące przejęcia przez Radziwiłłów dóbr neuburskich ${ }^{89}$. Każde dodatkowe koszty kanclerzyna uznawała za zbędne i przyjmowała z nieskrywanym niezadowoleniem. W liście do syna zanotowała: „przy moich biedach jeszcze musiałam i te akty weselne odprawić przy księdzu koadiutorze, który ślub dawał pannie Ancuciance z panem Chomińskim pisarzowicem litewskim, a po odjeździe jego zaraz drugi ślub nastąpił pana Mogilnickiego z panną Czarnecką"90.

Oprócz wydatków związanych z funkcjonowania radziwiłłowskiej kuchni, warto też zwrócić uwagę na inne aspekty życia dworskiego. Ciekawe zapisy dotyczą chociażby zastawy stołowej używanej przez kanclerzynę. Często wymieniane były elegancko zdobione farfury ${ }^{91}$,

${ }^{80}$ Gorzkie migdały trafiały nie tylko do cukierni. W jednym z zapisów wskazano, że jedna porcja ma zostać przekazana „na lekarstwo” dla posługującej na dworze krawcowej, AGAD, AR, dz. XXIX, rkps 29, s. 36.

${ }^{81}$ AGAD, AR, dz. XXIX, rkps 29, s. 23.

${ }^{82}$ AGAD, AR, dz. XXIX, rkps 29, s. 69.

83 AGAD, AR, dz. XXIX, rkps 29, s. 68.

${ }^{84}$ AGAD, AR, dz. XXIX, rkps 29, s. 250.

85 AGAD, AR, dz. XXIX, rkps 29, s. 250.

${ }^{86}$ AGAD, AR, dz. XXIX, rkps 29, s. 200.

87 AGAD, AR, dz. XXIX, rkps 29, s. 236.

88 AGAD, AR, dz. XXIX, rkps 29, s. 35.

89 Zob.: Lesiński J. 1996, s. 95-132.

90 AGAD, AR IV, nr 627, „Anna Katarzyna z Sanguszków Radziwiłłowa do Michała Kazimierza Radziwiłła, Biała, 9 I 1739”, s. 14. Małżeństwo Chomińskiego nie trwało długo. Już w kwietniu 1739 r. Anna Katarzyna zapisała w jednym z listów „Chomiński młody, który wziął Anuciankę, w łeb sobie strzelił, z tej tylko przyczyny, że ojciec jego laską miał go kilka razy uderzyć”. Dodawała też „ja tego małżeństwa nigdy nie życzyłam. Mówiłam i pannie, mówiłam i matce, w jednej płocha miłość, w drugiej niepomiarkowana ambicja przeważyły rady moje”, AGAD, AR IV, nr 627, „Anna Katarzyna z Sanguszków Radziwiłłowa do Michała Kazimierza Radziwiłła, Biała, 29 IV 1739”, s. 87.

${ }^{91}$ Farfur — termin z jęz. arabskiego, znaczący „fajans”. W Rzeczypospolitej terminem „farfury” zwyczajowo określano wyroby fajansowe, porcelanowe, a także malowane naczynia z gliny, zob. np.: Kowecka E. 1983, s. 10-11; więcej o osiemnastowiecznej modzie na porcelanę np. Roćko A. 2013, s. 131. 
najczęściej z ornamentem w kolorze błękitnym ${ }^{92}$ lub czerwonym i błękitnym oraz motywem kwiatowym $^{93}$. Kilka razy wspomniano, że farfury były różnego gatunku ${ }^{94}$. Wiele wyrobów pochodziło z „fabryki holenderskiej”, czyli farfurni działającej w Białej, przeorganizowanej przez kanclerzynę w 1738 r. ${ }^{95}$ Niektóre z dostarczonych na dwór naczyń oznaczano; w tym celu w 1739 r. przekazano „wosku żółtego do cukierni cukiernikowi do klejenia szkła na farfurkach”96, innym zaś razem zapas tego samego wosku miał posłużyć „do klejenia papieru koło farfur”97. Wśród zgromadzonych farfur były też wyroby specjalnego przeznaczenia — zastawa do picia kawy i herbaty ${ }^{98}$, czarki do podawania czekolady ${ }^{99}$ oraz dzbanuszki na mleko ${ }^{100}$. Dysponowano też licznymi talerzami ${ }^{101}$, filiżankami ${ }^{102}$, miseczkami, garnuszkami i kubkami, wyliczanymi bez wskazania co do ich zastosowania. W rejestrach wyróżniano też solniczki oraz niewielkie pojemniki na masło ${ }^{103}$.

Magnatka miała też do dyspozycji kilka kompletów naczyń porcelanowych. Zastawę uzupełniały naczynia „polewane”104 bialskiej, krakowskiej i słuckiej „roboty”, na których serwowano potrawy do pokojów Radziwiłłowej ${ }^{105}$. Na potrzeby kanclerzyny sprowadzano też zdobione kwiatami szklane kufle, często z cynowymi pokrywami („przykrywadełkami”) ${ }^{106}$. Wyrobami ze swych wytwórni kanclerzyna chętnie obdarowywała członków swej rodziny. W październiku 1739 r. kazała wysłać swej córce — kanclerzynie litewskiej, Konstancji Franciszce z Radziwiłłów Sapieżynie (†1756) i jej małżonkowi, Janowi Fryderykowi Sapiesze (†1751) ,garnitur ${ }^{107}$ do stołu z mojej fabryki, jako też i zwierciadełek parę z fabryki zwierciadlanej”108. Do przechowywania takich delikatnych i kruchych naczyń używano m.in. prostych, łubianych pudeł. W nich również farfurową i szklaną zastawę transportowano do aktualnych rezydencji kanclerzyny ${ }^{109}$.

Zachowane źródła dowodzą, że Anna Katarzyna lubiła się otaczać przedmiotami modnymi, lecz bynajmniej nie za wygórowaną cenę. Jeszcze w roku 1735 polecała swemu synowi, Hieronimowi Florianowi, by ten koniecznie przywiózł jej z zagranicy „farfur, które tam w Holandii będą tańsze”"110. Kanclerzyna radziła, by wyszukując interesujące przedmioty syn pamiętał również

92 AGAD, AR, dz. XXIX, rkps 29, s. 46.

93 AGAD, AR, dz. XXIX, rkps 29, s. 62.

94 AGAD, AR, dz. XXIX, rkps 29, s. 232.

95 Przyrembel Z. 1936, s. 42-43; Karkucińska W. 2000, s. 152. W. Karkucińska wnioskowała, że produkcja farfur w dobrach kanclerzyny najprawdopodobniej istniała już od końca lat dwudziestych XVIII w.

96 AGAD, AR, dz. XXIX, rkps 29, s. 61.

97 AGAD, AR, dz. XXIX, rkps 29, s. 95.

98 AGAD, AR, dz. XXIX, rkps 29, s. 46; Inwentarz pośmiertny. 2016. s. 58.

99 AGAD, AR, dz. XXIX, rkps 29, s. 164.

100 AGAD, AR, dz. XXIX, rkps 29, s. 123.

101 AGAD, AR, dz. XXIX, rkps 29, s. 164.

102 AGAD, AR, dz. XXIX, rkps 29, s. 123

103 AGAD, AR, dz. XXIX, rkps 29, s. 123.

104 Jako naczynia polewane, czyli pokryte warstwą szkliwa, określane były m.in. wyroby półfajansowe, por. np.: Trzeciecki M. 2017, s. 184. Polewanie, czyli szkliwienie, podnosiło przede wszystkim jakość naczyń glinianych, zwiększając nieprzesiąkliwość czerepów, dodawało im także ozdobności.

105 AGAD, AR, dz. XXIX, rkps 29, s. 62.

106 AGAD, AR, dz. XXIX, rkps 29, s. 62.

107 Terminem „garnitur” określano pełną zastawę stołową.

108 AGAD, AR IV, nr 627, „Anna Katarzyna z Sanguszków Radziwiłłowa do Jana Fryderyka Sapiehy, Biała, 22 X 1739”, s. 182.

109 AGAD, AR, dz. XXIX, rkps 29, s. 61.

110 AGAD, AR IV, nr 624, „Anna Katarzyna z Sanguszków Radziwiłłowa do Hieronima Floriana Radziwiłła, Biała, 23 V 1735”, s. 162. 
o sobie: „przysposób sobie serwis jeden i drugi, według pomiarkowania się z pieniędzmi twymi, a dobrze by garniturę mieć jedną i drugą i jaszcze ${ }^{111}$, które bywają na pierwsze noszenie”. Księżna pragnęła również „zastawić wszystek stół nakrytymi jaszczami”" ${ }^{112}$. Poza tym, zgodnie z jej życzeniem, Hieronim Florian miał wysondować, czy zagranicą w użyciu i sprzedaży jest jeszcze „coś oryginalnego” „do cukrów jeżeli zażywają" ${ }^{113}$. Niepewna co do specyfiki oferowanych tam wyrobów zdała się w pełni na gust syna, dodając: „lepiej tam obaczysz co modnego”114.

Swoje upodobania co do zastawy stołowej kanclerzyna wyjawiła zaś jasno w jednym z listów kierowanych do drugiego z synów, Michała Kazimierza. Polecała, by ten, przebywając zagranicą, również nie zapomniał kupić dla niej naczyń farfurowych i serwisów. Korespondencja między matką i synem stanowi dodatkowe poświadczenie wcześniejszych wniosków, że magnatka nie chciała tracić fortuny na wyposażenie dworu w prestiżowe i dekoracyjne, lecz jednocześnie bardzo drogie przedmioty. Zaznaczyła więc: „strzeż się tych kupować bardzo pięknych co się zowią vieille porcelaine, bo ta jest bardzo droga, ale są teraźniejsze ładne, a nie tak drogie, byleby nie fajanse, bo ta jest zbytnio prosta, nic nam po niej”115. Zamiast przedmiotów z tych surowców kanclerzyna wolała sprowadzić „garnitury, żeby były do zastawienia stołu i z jaszczami do zup, drugie zaś bywają garnitury wszystkie w jaszczach nakryte, wielkie i małe, to te są bardzo ładne i bardzo estymowane takie serwisy, kiedy tedy dostaniesz takie, to te kupić”116.

Poza krajem księżna nabywała też srebra stołowe. Uważała, że tego typu sprawunki najlepiej robić w Lipsku lub Berlinie ${ }^{117}$. Choć wydawać by się mogło, że liczba talerzy, sztućców i innych elementów wchodzących w skład zastawy stołowej zgromadzonej na dworze była imponująca, to Michałowi Kazimierzowi, jadącemu w 1739 r. na święta wielkanocne do Białej, radziła: „z srebra ze dwa tuziny półmisków wziąć i talerzy ze dwa tuziny, a resztę wszystko się tu znajdzie"118. Natomiast odradzała mu pomysł przywiezienia własnego kuchmistrza, a także zabierania prywatnych serwet i obrusów.

Wiele innych rzeczy codziennego użytku było tańszych i mało wyszukanych. Pojedyncze wzmianki w analizowanych rejestrach dotyczą naczyń miedzianych. Warto jednak odnotować, że te, które sprowadzano na potrzeby kanclerzyny, zazwyczaj były nowe ${ }^{119}$. Wśród wyrobów zrobionych z tego stopu najczęściej notowano pojedyncze dzbanuszki miedziane z uszkami na kawę ${ }^{120}$. Natomiast z cyny wykonane były sprzęty używane przede wszystkim podczas niezbędnych prac gospodarskich; były to: łyżki do robienia świec, konwie do ogrodu, alembiki niezbędne w aptece ${ }^{121}$.

111 Jaszczykami nazywano drobne naczynia, na przykład na masło czy powidła, zob.: Przyrembel Z. 1936, s. 314.

112 AGAD, AR IV, nr 624, „Anna Katarzyna z Sanguszków Radziwiłłowa do Hieronima Floriana Radziwiłła, Biała, 23 V 1735”, s. 162.

113 AGAD, AR IV, nr 624, „Anna Katarzyna z Sanguszków Radziwiłłowa do Hieronima Floriana Radziwiłła, Biała, 23 V 1735”, s. 162.

114 AGAD, AR IV, nr 624, „Anna Katarzyna z Sanguszków Radziwiłłowa do Hieronima Floriana Radziwiłła, Biała, 23 V 1735”, s. 163.

115 AGAD, AR IV, nr 624, „Anna Katarzyna z Sanguszków Radziwiłłowa do Michała Kazimierza Radziwiłła, Biała, 29 V 1735”, s. 174.

${ }^{116}$ AGAD, AR IV, nr 624, „Anna Katarzyna z Sanguszków Radziwiłłowa do Michała Kazimierza Radziwiłła, Biała, 29 V 1735”, s. 175.

117 AGAD, AR IV, nr 624, „Anna Katarzyna z Sanguszków Radziwiłłowa do Michała Kazimierza Radziwiłła, Biała, 29 VI 1735”, s. 194

118 AGAD, AR IV, nr 627, „Anna Katarzyna z Sanguszków Radziwiłłowa do Michała Kazimierza Radziwiłła, Biała, 4 III 1739”, s. 54.

${ }^{119}$ AGAD, AR, dz. XXIX, rkps 29, s. 108.

120 AGAD, AR, dz. XXIX, rkps 29, s. 108.

121 AGAD, AR, dz. XXIX, rkps 29, s. 108. 
Generalnie wiele przedmiotów wspomnianych w badanych źródłach było nie tylko tańszych, ale też mocno zużytych. Dążono jednak do ich racjonalnego, dalszego wykorzystania, np. metale przeznaczano do przetopienia i wykonania z nich nowych elementów. I tak, od starych okien „odkuwano ołów” (tzn. demontowano ołowiane ramki, w które wprawione były szyby), aby w ten sposób zyskać materiał do „oblania” „różnych garnków, tyglów dopalenia kawy i tygielków”122. Wykorzystywano w tym celu proste tygielki gliniane. Część nowych wyrobów trafiała potem bezpośrednio do komnat kanclerzyny ${ }^{123}$. Stare i połamane łopatki żelazne, używane wcześniej przez ogrodnika, kazano przerobić na śruby do krzesła znajdującego się w pokoju Anny Katarzyny ${ }^{124}$. Od spalonych kolasek odkuwano żelazo, z którego wykonywano zawiasy lub obręcze. Służyły również do przeprowadzenia drobnych napraw bram, schodów, skrzyń itp. ${ }^{125}$

Podobnie postępowano z różnymi częściami używanej odzieży, tj. nie pozbywano się ich, lecz znajdowano dla nich nowe zastosowanie. W jednym z wpisów nadmieniono, że od szarego lokajskiego odzienia, „obłożonego złotymi galonami ${ }^{126 ”, ~ k a z a n o ~ o w e ~ g a l o n y ~ o d p r u c ́ ~ i ~ „ o d d a n o ~}$ do pokoju księżnej Dobrodz[iejki]”127. Tak zwane „krajki od sukna dobrego”, czyli drobne fragmenty droższych materiałów, pozostałe po uszyciu określonych elementów garderoby, z rozmysłem przeznaczano na inny cel. Robiono z nich m.in. pasy dla służby i karłów ${ }^{128}$. Odświeżano też różne części ubioru należące do służby, jak choćby kapelusze lokajskie, które potem otrzymywały kolejne zatrudniane osoby ${ }^{129}$.

Rejestry obejmowały też zakup artykułów służących higienie, z zaznaczeniem, które z nich sprowadzano wyłącznie dla Anny Katarzyny. Do takich rzeczy należało białe mydło węgierskie „na ręce”130. Stosowano je również do czyszczenia niektórych elementów odzieży magnatki, w tym strojnych kornetów ${ }^{131}$. Bardzo często wzmiankowano też o używaniu na dworze mydła „zabłudowskiego”132, traktowanego jako „najpośledniejsze”133. Stosowano je do rozmaitych prac gospodarskich, m.in. do mycia zwierząt domowych oraz „do chędożenia pędzlów” malarskich $^{134}$. Mydło określane jako warszawskie wydawane było przede wszystkim pracującym na dworze rzemieślnikom ${ }^{135}$.

Na potrzeby dworu kanclerzyny regularnie kupowano dużą ilość świec. Dzielono je na te, trafiające bezpośrednio do pokojów Radziwiłłowej, oraz te, przeznaczone dla pracowników różnych profesji ${ }^{136}$. W tym przypadku najczęściej były to białe świece woskowe. Osobno rejestrowano też „świece podróżne”, zarówno na potrzeby kanclerzyny, jak i jej najbliższych krewnych $^{137}$. Żółte świece miały zaś oświetlać wnętrze kaplicy zamkowej a wraz z kilkoma świecami białymi również „kościół farny” i „lustro szklane” w tej świątyni ${ }^{138}$.

122 AGAD, AR, dz. XXIX, rkps 29, s. 29.

123 AGAD, AR, dz. XXIX, rkps 29, s. 62.

124 AGAD, AR, dz. XXIX, rkps 29, s. 118.

125 AGAD, AR, dz. XXIX, rkps 29, s. 180.

${ }^{126}$ Galony — taśmy lub lamówki z nici, najczęściej w kolorze złotym lub srebrnym.

127 AGAD, AR, dz. XXIX, rkps 29, s. 102.

128 AGAD, AR, dz. XXIX, rkps 29, s. 135.

129 AGAD, AR, dz. XXIX, rkps 29, s. 109

130 AGAD, AR, dz. XXIX, rkps 29, s. 45.

131 AGAD, AR, dz. XXIX, rkps 29, s. 143. Kornety były ozdobnym nakryciem głowy, które zyskało popularność w XVIII w. Nową modę z przekąsem komentował Jędrzej Kitowicz, zob.: Kitowicz J. 2003, s. 532; Penkała A. 2016, s. 321-322.

132 Rzeczy zabłudowskie - przywożone z majątku zabłudowskiego Radziwiłłów.

133 AGAD, AR, dz. XXIX, rkps 29, s. 97.

134 AGAD, AR, dz. XXIX, rkps 29, s. 155.

135 AGAD, AR, dz. XXIX, rkps 29, s. 204.

136 AGAD, AR, dz. XXIX, rkps 29, s. 61.

137 AGAD, AR, dz. XXIX, rkps 29, s. 61.

138 AGAD, AR, dz. XXIX, rkps 29, s. 61. 
Z uwagi na specyfikę analizowanego materiału źródłowego wskazać można, co zaznaczono już wcześniej, towary sprowadzane na dwór tylko przy szczególnych okazjach, takich jak jubileusze i obchody związane z rokiem liturgicznym. Na przykład tuż przed Wielkanocą przywożono zapas „pochodni woskowych białych na procesję na wielki czwartek”139.

Zachowane rejestry pozwalają też określić, w jakie materiały — sukna i tkaniny, zaopatrywany był dwór kanclerzyny. Wybierano tkaniny określonej jakości, przede wszystkim zależnie od ich przeznaczenia. Najczęściej sprowadzano tańsze, potrzebne do codziennych czynności, zwłaszcza do prac porządkowych, oraz służące jako obicia do skrzyń mających pomieścić rozmaite przedmioty. W tym celu zużywano głównie zgrzebne płótno, które stosowano w różnym celu: „na worki na korzenie”, „na parawan”, „na ścierki” - „do wycierania beczek i antałów” i „, do kredensu do wycierania srebra i cyny w drodze”140. Płótno lniane wykorzystywano do obijania drzwi pokojów i gabinetów księżnej ${ }^{141}$. Przede wszystkim z prostego białego sukna szyto spodnie dla chłopców posługujących na dworze. Sukno granatowe przeznaczano na żupany, zaś proste „płótno zgrzebne” jako podszycie pod nie ${ }^{142}$. Z kolei poszewki dla dziewek pracujących dla dworu wykonywano najczęściej z prostego „płótna zgrzebnego białego pod kamizelki i spódnice" ${ }^{143}$.

Materiały droższe przeznaczane były przede wszystkim dla samej Radziwiłłowej oraz dla członków jej najbliższej rodziny. Z nich szyto różne elementy odzienia, m.in. kamizele grodeturowe i podszyte kraszeniną ${ }^{144}$, suknie kitajkowe, a także „suknie maszkaradne”, ponadto czapki „bogate” i atłasowe, kapelusze ${ }^{145}$, pióra do kapeluszy ${ }^{146}$, angażanty ${ }^{147}$ i wiele innych ${ }^{148}$. Kanclerzyna pozwalała swoim bliskim korzystać z drogich ubiorów przechowywanych we dworze. W liście do Czarneckiego, pełniącego u niej służbę, kanclerzyna polecała np. aby przekazać synowi Michałowi Kazimierzowi „pas szafirowy”, który „jest w szkatule klejnotowej w skarbcu [...] jeżeli go będzie chciał wziąć niech sobie zdrów weźmie”"149.

Różne zastosowanie miały też skóry. Składając zamówienie na oprawienie książek przez introligatora, przeznaczono na ten cel „skóry cielęce szare, na futerał do książki”150. Innym razem wspominano też o użyciu do tego celu czerwonych skórek koźlęcych ${ }^{151}$. Szare skóry zużywano też do wykonania lub reperowania innych przedmiotów codziennego użytku, jak choćby „naprawienia kałamarza starego” należącego do Radziwiłłowej ${ }^{152}$. Z białych skór wykonywano zaś trzewiki ${ }^{153}$ i patynki ${ }^{154}$. Ze skór danieli, a przy tym „na obiedwie strony wypraw-

139 AGAD, AR, dz. XXIX, rkps 29, s. 61.

140 AGAD, AR, dz. XXIX, rkps 29, s. 37.

141 AGAD, AR, dz. XXIX, rkps 29, s. 148.

142 AGAD, AR, dz. XXIX, rkps 29, s. 39.

143 AGAD, AR, dz. XXIX, rkps 29, s. 148.

144 AGAD, AR, dz. XXIX, rkps 29, s. 37, kraszenina - barwione, woskowane płótno.

145 AGAD, AR, dz. XXIX, rkps 29, s. 38.

146 AGAD, AR, dz. XXIX, rkps 29, s. 39.

147 Angażant — forma rękawa lub mankietu w ubiorze kobiecym.

148 Zakupy niektórych materiałów kanclerzyna zlecała najbliższym krewnym. Jeszcze w 1732 r. jej córka, Karolina Teresa z Radziwiłłów Sapieżyna, pisała do matki w sprawie zakupu materiałów, jakie poczyniła na jej zamówienie na Jarmarku Dominikańskim w Gdańsku, AGAD, AR V, nr 13898/III, „Karolina Teresa z Radziwiłłów Sapieżyna do Anny Katarzyny z Sanguszków Radziwiłłowej, Gdańsk, 17 VIII 1732”, s. 83-84.

149 AGAD, AR IV, nr 623, „Anna Katarzyna z Sanguszków Radziwiłłowa do Michała Kazimierza Radziwiłła, Człuchów, 23 VII 1733”, s. 78.

150 AGAD, AR, dz. XXIX, rkps 29, s. 23.

151 AGAD, AR, dz. XXIX, rkps 29, s. 70.

152 AGAD, AR, dz. XXIX, rkps 29, s. 51.

153 AGAD, AR, dz. XXIX, rkps 29, s. 51.

154 AGAD, AR, dz. XXIX, rkps 29, s. 70. 
nych”, robione były rękawiczki dla Anny Katarzyny ${ }^{155}$ oraz elementy ozdobne, np. w 1739 r. z tego surowca wykonano strojne obicie zagłówka do jej łoża ${ }^{156}$. Czarne skóry wołowe pozyskiwano z zamiarem uszycia z nich prostego obuwia dla pachołków kanclerzyny ${ }^{157}$, zwłaszcza podeszw ${ }^{158}$. Czarne skórki koźlęce miały wiele zastosowań, m.in. przerabiano je na pokrowce potrzebne w trakcie podróży odbywanych przez magnatkę . Stanowiły zabezpieczenie przewożonych, niewielkich skrzynek i pudełek ${ }^{159}$. Czarne i czerwone skóry juchtowe ${ }^{160}$ wykorzystywano sporadycznie i to wyłącznie w celach dekoracyjnych; obijano nimi stoły, przede wszystkim nowo wykonane, przeznaczone „do pokoju dla księżnej”161. W jednym przypadku ze skór tych miał być zrobiony centralny ornament mebla ${ }^{162}$.

Na podstawie badanych rejestrów można określić, w jakie przedmioty wyposażano wówczas prywatne pokoje kanclerzyny. Na początku roku 1739 zakupiono na jej użytek puzdro wyklejone zielonym aksamitem, a do niego kilka kompletów łyżek, w tym dwanaście „cynowych angielskich” i osiem białych, oraz kilka malowanych na złoto do kawy ${ }^{163}$. Do przechowywania różnych drobiazgów wykonywano zresztą dla niej rozliczne pudła (najczęściej proste, łubiane ${ }^{164}$ lub bardziej eleganckie — wyklejane kirem ${ }^{165}$ ) i sepety, a także pomniejsze „puzderka”, koniecznie zamykane ${ }^{166}$. Wspominano też o nabywaniu dla Anny Katarzyny „,nowych pudełeczek blaszanych”, służących m.in. do przechowywania niewielkich ilości herbaty ${ }^{167}$. Nie brak także wzmianek o pojemnikach droższych i kunsztowniej zdobionych. Do takich zaliczały się pojedyncze sprzęty, w tym: szkatułki zdobione obrazkami malowanymi na płótnie ${ }^{168}$, sepet „nowy, czarną skórą obity z herbem, we środków płótnem wyklejony”169 oraz zrobione ze skóry przez introligatora „puzderko na ordery” ${ }^{170}$. Wśród sprzętów do przechowywania zastosowanie miały także „futeraliki” wyklejone czerwonym kirem, w których trzymano niewielkie lusterka ${ }^{171}$. Na potrzeby magnatki wykonano też kilka szaf, które malarze mieli później pomalować używając grynszpanu ${ }^{172}$. Inne obijano skórami, w tym barwioną na czerwono skórką koźlęcą ${ }^{173}$. Zestaw uzupełniały malowane „szafy chińskie” ${ }^{174}$. W swej prywatnej przestrzeni kanclerzyna mogła też korzystać ze „stolika składanego, suknem zielonym wybitego, nowego, pod nim nogi

155 AGAD, AR, dz. XXIX, rkps 29, s. 70.

156 AGAD, AR, dz. XXIX, rkps 29, s. 159.

157 AGAD, AR, dz. XXIX, rkps 29, s. 88.

158 AGAD, AR, dz. XXIX, rkps 29, s. 102.

159 AGAD, AR, dz. XXIX, rkps 29, s. 88.

160 Skóry juchtowe - skóry szlachetne, garbowane, o dużej wytrzymałości, wyprawiane najczęściej ze skóry bydlęcej.

161 AGAD, AR, dz. XXIX, rkps 29, s. 147.

162 AGAD, AR, dz. XXIX, rkps 29, s. 51.

163 AGAD, AR, dz. XXIX, rkps 29, s. 30.

164 AGAD, AR, dz. XXIX, rkps 29, s. 80.

165 AGAD, AR, dz. XXIX, rkps 29, s. 102.

166 AGAD, AR, dz. XXIX, rkps 29, s. 78. Wśród zapisów są też wzmianki poświadczające regularne wykonywanie dla kanclerzyny kolejnych, nowych puzderek, AGAD, AR, dz. XXIX, rkps 29, s. 93.

167 AGAD, AR, dz. XXIX, rkps 29, s. 107.

168 AGAD, AR, dz. XXIX, rkps 29, s. 82.

169 AGAD, AR, dz. XXIX, rkps 29, s. 124. Wskazany sepet miał później zostać podarowany jednej z córek Mikołaja Faustyna Radziwiłła (†1746), wojewody nowogrodzkiego.

170 AGAD, AR, dz. XXIX, rkps 29, s. 132.

171 AGAD, AR, dz. XXIX, rkps 29, s. 133.

172 AGAD, AR, dz. XXIX, rkps 29, s. 83. Grynszpan — związek wykorzystywany do uzyskania zielonego zabarwienia farb.

173 AGAD, AR, dz. XXIX, rkps 29, s. 133.

174 AGAD, AR, dz. XXIX, rkps 29, s. 139. 
snycerskiej roboty”175, a także ze stolika malowanego, obijanego płótnem ${ }^{176}$. Pomiędzy tzw. pokojem „złotym”177 a jednym z prywatnych pokoi księżnej co pewien czas przestawiano też „stół kamienny duży malowany” ${ }^{178}$. W innych zaś miał stać „stół chiński czarny”, obity mosiądzem $^{179}$ (regularnie polerowany tryplą ${ }^{180}$ ) oraz mniejsze stoliki marmurowe ${ }^{181}$. Interesujący jest zapis potwierdzający zamówienie w 1739 r. dla podstarzałej już magnatki „skóry juchtowej czerwonej na stołek i na pasy do noszenia Księżnej Jejmości Dobrodz[iejki] i na paski podłużne do krzesła, do ławki pod nogi”"182.

W rejestrach wspominano nie tylko o wykonywaniu, ale też o reperowaniu wielu mebli, w tym tych na prywatny użytek Radziwiłłowej. Wśród wzmiankowanych przedmiotów znajdowały się: okuwane żelazem łóżko, okuwany żelazem tapczan, składany stołek podróżny ${ }^{183}$, nowa „wielka kanapa” ${ }^{184}$, a także liczne „krzesełka” o różnych wielkościach ${ }^{185}$. Kanclerzyna życzyła sobie, aby meble wytwarzane przez rodzimych rzemieślników wzorowane były na modelach zachodnich. O wzory do wytworzenia tych sprzętów oraz obić kanclerzyna starała się osobiście. W tym celu nakazała Michałowi Kazimierzowi kolekcjonować w trakcie zagranicznych podróży różne „obrysy, jako to tapicerskie, snycerskie i do różnych robót ołtarzy, stolików etc.” ${ }^{186}$. W lipcu 1739 r. przypominała się listownie synowi: „od ciebie miała być taka kapa według tamtej formy, jaka tamta była, bo bez modelu nie potrafią drugiej takiej zrobić”187. Zgodnie z zamówieniem, w tym samym roku do jednego z prywatnych pokoi kanclerzyny sprawiono nową kanapę oraz przeznaczone do niej wał i poduszki z dartego pierza ${ }^{188}$.

Anna Katarzyna chętnie przyjmowała też meble jako gustowne podarunki. W lutym $1740 \mathrm{r}$. dziękowała synowi Michałowi Kazimierzowi, że ten przysłał jej stół „,bardzo ładny”189. Oczarowana prezentem zapowiedziała „takie każę zaraz tu u siebie robić i mam nadzieję w Panu Bogu, że moi takie potrafią" ${ }^{190}$. Wykonane dla kanclerzyny pozostałe łóżka wykładano skórzanymi poduszkami z „pierzem dartym”, uzupełniając je czarnymi skórzanymi piernatami, wypełnionymi w ten sam sposób ${ }^{191}$. Puch pozyskany w dobrach Radziwiłłowej ofiarowywano też bliskim

175 AGAD, AR, dz. XXIX, rkps 29, s. 45.

176 AGAD, AR, dz. XXIX, rkps 29, s. 252.

177 O pokoju złotym Anna Katarzyna wspominała też w prywatnej korespondencji. Zaznaczała, że w zimie jest to jedyne miejsce, w którym jest w stanie utrzymać ciepło, AGAD, AR IV, nr 627, „Anna Katarzyna z Sanguszków Radziwiłłowa do Hieronima Floriana Radziwiłła, Biała, 13 I 1740”, s. 216.

178 AGAD, AR, dz. XXIX, rkps 29, s. 45.

179 AGAD, AR, dz. XXIX, rkps 29, s. 58.

180 AGAD, AR, dz. XXIX, rkps 29e, s. 65. Trypla — inaczej łupek polerski; inne meble należące do kanclerzyny szlifowano przy użyciu skór ryb morskich (lub ssaków morskich?), zob.: AGAD, AR, dz. XXIX, rkps 29, s. 89.

181 AGAD, AR, dz. XXIX, rkps 29, s. 83.

182 AGAD, AR, dz. XXIX, rkps 29, s. 116

183 AGAD, AR, dz. XXIX, rkps 29, s. 55.

184 AGAD, AR, dz. XXIX, rkps 29, s. 138.

185 AGAD, AR, dz. XXIX, rkps 29, s. 78.

186 AGAD, AR IV, nr 624, „Anna Katarzyna z Sanguszków Radziwiłłowa do Michała Kazimierza Radziwiłła, Biała, 29 VI 1735”, s. 195.

187 AGAD, AR IV, nr 627, „Anna Katarzyna z Sanguszków Radziwiłłowa do Michała Kazimierza Radziwiłła, Biała, 12 VII 1739”, s. 137.

188 AGAD, AR, dz. XXIX, rkps 29, s. 154.

189 AGAD, AR IV, nr 627, „Anna Katarzyna z Sanguszków Radziwiłłowa do Michała Kazimierza Radziwiłła, Biała, 7 II 1740”, s. 242.

190 AGAD, AR IV, nr 627, „Anna Katarzyna z Sanguszków Radziwiłłowa do Michała Kazimierza Radziwiłła, Biała, 7 II 1740”, s. 242.

191 AGAD, AR, dz. XXIX, rkps 29, s. 63. 
księżnej. I tak np. w 1740 r. magnatka obiecała posłać jego partię do Michała Kazimierza, polecając przy tym, aby „Jędrzej tapiserz, wziął lokajów ze dwóch twoich i sam nasypywał”192.

Na podstawie zachowanych rejestrów nietrudno ustalić przeznaczenie wielu omawianych rzeczy, gdyż w sposób klarowny zaznaczano, że są one przygotowywane na osobiste potrzeby „Księżnej Jejmość Dobrodziejki”. Pozwala to przybliżyć nieco wystrój pomieszczeń przez nią zajmowanych.

Wyposażenie wnętrz uzupełniały drobne przedmioty ze złota i srebra. Przynajmniej w kilku pokojach znajdowały się zegary, regularnie reperowane ${ }^{193}$. Ponadto czasami zamawiano srebrne lichtarze i kadzidła ${ }^{194}$. W marcu 1739 r. zakupiono surowce, które miały posłużyć do wykonania „podłogi dębowej nowej w pokoju Księżnej Jejmości Dobrodziejki” ${ }^{195}$. Do innego zaś wnętrza zlecono „farbowanie żółto wełny na wybicie podłogi w pokoju Księżnej”"196. Ściany były obijane rozmaitymi materiałami. Pracę tę wykonywali zatrudnieni na dworze tapicerzy ${ }^{197}$.

Interesujące są również zapisy o przedmiotach dla dzieci. Wśród pudeł zakupionych na początku roku 1739 znajdowało się jedno „małe, podługowate, na upakowanie zabawek dziecinnych różnych”, które posłano dla dzieci jednej z córek kanclerzyny — Karoliny Teresy z Radziwiłłów Sapieżyny ${ }^{198}$. Wśród wydatków z marca tego samego roku odnotowano z kolei pełną listę zabawek wysłanych dla tych wnuków ${ }^{199}$. Ponieważ tego rodzaju wykazy są stosunkowo rzadkie ${ }^{200}$, warto przytoczyć wszystkie rzeczy przekazane wówczas najmłodszym. Wśród podarków znalazły się: „Klatka drewniana okrągła mała z papugą, kareta wielka na pasach o 4 koniach i z 3ma osobami i biegun pozłocisty na desce ${ }^{201}$, pistolet mały, żołnierzy piechoty (9), dragonii konnej (21), pudełko piechoty ${ }^{202}$, postument z kulami na drocie, koń z osobą na postumencie zielonym, kawaler na desce żółty bez rąk”203. Zabawki odzwierciedlały więc życie dworskie i popularne rozrywki. Wszystkie miały być kunsztownie wykonane tak, aby cieszyć oko małych właścicieli.

Nie były to jedyne przedmioty dziecięce, jakie tam dostarczono. Świadectwem tego jest zachowana korespondencja. Chociażby w kwietniu 1736 r. Karolina Teresa upraszała matkę, by ta wysłała jej z Białej kilka butelek, dodając „tu u nas wcale nigdzie nie dostanie, a są mi bardzo potrzebne w ten czas na przepędzenie i destylowanie różnych wód dla dzieci” ${ }^{204}$. W innym zaś liście poświadczała, że zatrudniony na usługach Radziwiłłowej architekt Deshomme, mając na uwadze „łatwość do chodzenia dzieciom”, przysłał jej „robotę tokarską”. Dodawała jednak „czego u nas zrobić nie potrafią, ale [...] z kart sama zrobiłam model i każę tu zrobić swoim rzemieślnikom”205.

192 AGAD, AR IV, nr 628, „Anna Katarzyna z Sanguszków Radziwiłłowa do Michała Kazimierza Radziwiłła, Biała, 3 IX 1740”, s. 75.

193 AGAD, AR, dz. XXIX, rkps 29, s. 60.

194 AGAD, AR, dz. XXIX, rkps 29, s. 109

195 AGAD, AR, dz. XXIX, rkps 29, s. 56.

196 AGAD, AR, dz. XXIX, rkps 29, s. 111.

197 AGAD, AR, dz. XXIX, rkps 29, s. 56.

198 AGAD, AR, dz. XXIX, rkps 29, s. 46. Zakup zabawek dla dzieci Karoliny Teresy nie był przypadkowy. Matka i córka utrzymywały bardzo bliskie relacje, a córka często radziła się matki w sprawach wychowania i opieki nad dziećmi, zob.: Penkała-Jastrzębska A. 2019, s. 69-82.

199 Więcej o zabawkach na magnackich dworach w: Kabacińska K. 2010, s. 130-131.

200 Zob.: Żołądź-Strzelczyk D. 2013, s. 13.

201 Na znikomą liczbę tego rodzaju zabawek w źródłach z epoki zwracano uwagę w: Żołądź-Strzelczyk D. 2013, s. 21.

${ }^{202}$ O takich zabawkach w domach szlacheckich w: Ryś J. 2010, s. 137-148.

203 AGAD, AR, dz. XXIX, rkps 29, s. 62.

204 AGAD, AR V, nr 13898/V, „Karolina Teresa z Radziwiłłów Sapieżyna do Anny Katarzyny z Sanguszków Radziwiłłowej, Wysokie, 21 IV 1736”, s. 10.

205 AGAD, AR V, nr 13898/V, „Karolina Teresa z Radziwiłłów Sapieżyna do Anny Katarzyny z Sanguszków Radziwiłłowej, Wysokie, 5 XII 1736”, s. 44. 
Własnością tytułowej bohaterki były różne środki transportu oraz konie przysposobione do ciągnięcia zaprzęgu. W rejestrze wspominane są wydatki na „cug myszaty”206 „, „ug gniady 207”, „cug angielski” ${ }^{208}$, „cug kasztanowaty”209 oraz „cug kary pruski”210. W stajniach należących do kanclerzyny trzymano też „ogiery tureckie” ${ }^{211}$. Wśród powozów wyróżniano kilka: kolaski i wozy dzieląc je na te, które miały służyć osobom postronnym, od tych przeznaczonych wyłącznie dla Radziwiłłowejej ${ }^{212}$ Miała ona do dyspozycji zarówno powozy podróżne, jak i te, służące jej na co dzień. Do drugiej kategorii zaliczała się np. „kolaska żółta księżnej JejMości Dobr[odziejki], którą się wozi po ogrodzie i po dziedzińcu” ${ }^{213}$. Pozostałe charakteryzowano według prognozowanego zastosowania, jak choćby nowy „wózek na parę koni, którym pojedzie Jegomość P[an] Otton, podskarbi Księżnej Jejmość Dobrodz[iejki], do Wilna”214. W 1739 r. odnotowano też nakłady na rzecz przysposobienia „karety czerwonej, która przyszła z Warszawy”215. W tym samym roku zakupiono też nową kolaskę, którą następnie dostosowano do wymagań kanclerzyny ${ }^{216}$. Kolaski, w których miała podróżować, obijano wewnątrz skórami i harasem ${ }^{217}$. Przy ich zakupie, podobnie jak w przypadku innych przedmiotów, kanclerzyna zalecała rozsądne wydatki. Kiedy Hieronim Florian oferował jej możliwość zakupu we Francji przepięknego powozu, odpisała mu: „strony półkarocy o której pisałeś [...] ja tak bogatych nie chcę, od sześciu, od siedmiu tysięcy talerów, najwięcej od tysiąca, albo półtora tysiąca talerów”218. Powściągliwość w wydawaniu pieniędzy na podobne zbytki kanclerzyna zalecała też synowi, zaznaczając, iż nie sądzi, aby „tej magnificencji potrzebował”219. Dodawała jednocześnie, że dopiero jak „przyjdzie do ożenienia, na ten czas się sporządzi, teraz zaś kupiwszy, to by przez ten czas starzał się i nie był w modzie ten fason" 220 .

Formą urozmaicenia życia na magnackim dworze było trzymanie różnych zwierząt. Anna Katarzyna miała przede wszystkim kilka gromad psów, wśród nich „saksońskie” i charty, dla których niekiedy robiono nowe obroże ${ }^{221}$. Zapisy w analizowanych rejestrach przybliżają nieco koszty związane z pielęgnacją i utrzymaniem tych czworonogów. Wśród zakupionych towarów

${ }^{206}$ AGAD, AR, dz. XXIX, rkps 29, s. 43.

207 AGAD, AR, dz. XXIX, rkps 29, s. 43.

${ }^{208}$ AGAD, AR, dz. XXIX, rkps 29, s. 75.

${ }^{209}$ AGAD, AR, dz. XXIX, rkps 29, s. 78.

${ }^{210}$ AGAD, AR, dz. XXIX, rkps 29, s. 78.

211 AGAD, AR, dz. XXIX, rkps 29, s. 116.

${ }^{212}$ AGAD, AR, dz. XXIX, rkps 29, s. 75.

${ }^{213}$ AGAD, AR, dz. XXIX, rkps 29, s. 241.

${ }^{214}$ AGAD, AR, dz. XXIX, rkps 29, s. 119.

${ }^{215}$ AGAD, AR, dz. XXIX, rkps 29, s. 107.

${ }^{216}$ AGAD, AR, dz. XXIX, rkps 29, s. 147.

${ }^{217}$ AGAD, AR, dz. XXIX, rkps 29, s. 186. Haras — szorstka, lekka tkanina wehniana.

${ }^{218}$ AGAD, AR IV, nr 624, „Anna Katarzyna z Sanguszków Radziwiłłowa do Hieronima Floriana Radziwiłła, Biała, 22 VII 1735”, s. 204.

${ }^{219}$ AGAD, AR IV, nr 624, „Anna Katarzyna z Sanguszków Radziwiłłowa do Hieronima Floriana Radziwiłła, Biała, 22 VII 1735”, s. 204.

${ }^{220}$ AGAD, AR IV, nr 624, „Anna Katarzyna z Sanguszków Radziwiłłowa do Hieronima Floriana Radziwiłła, Biała, 22 VII 1735”, s. 204. Hieronim Florian przebywał wówczas w Mannheim, gdzie negocjowano sprawę jego małżeństwa z księżniczką Marią Franciszką von Sulzbach — wnuczką skoligaconego z Radziwiłłami elektora, Karola III Filipa Wittelsbacha, który był drugim mężem Ludwiki Karoliny z Radziwiłłów (†1695). Stąd właśnie zalecenia matki, aby nową karocą zainteresować się dopiero, gdy ustalona zostanie data ślubu z panną. Do małżeństwa tego jednak nie doszło, zob. Skrzypietz A. 2013, s. 103-114.

${ }^{221}$ AGAD, AR, dz. XXIX, rkps 29, s. 26. 
uwzględniono chociażby porcję „szafranu na lekarstwo dla psów saskich”222. Na polecenie kanclerzyny psy szczególną opieką otaczano podczas chłodnych miesięcy. Ze smutkiem patrzyła bowiem na to, jak marzną „tu na miejscu w izbach, choć kazałam jak najcieplej trzymać i słomą wyścielać”223. Mimo tych zabiegów, jak sama przyznała, zwierzęta „niewytrzymały tych mrozów i już kilka zamarzło"224.

Na podstawie zachowanego materiału źródłowego można wnioskować, że kanclerzyna miała też przynajmniej jednego własnego pupila — pieska „domowego”. Zamawiając zapas środków czyszczących na potrzeby dworu wykazywano bowiem, żeby pamiętać o zakupie porcji mydła zabłudowskiego lub warszawskiego do mycia Bobaka ${ }^{225}$, „pieska księżnej Jej Mość Dobrodz[iejki]”226. Oprócz tego, na dworze Radziwiłłowej pozostał „mops stary”, należący do Hieronima Floriana Radziwiłła ${ }^{227}$.

Magnatka lubiła też ptaki. Na dworze chowano kanarki; do opieki nad nimi zatrudniano osobną służbę ${ }^{228}$. Co pewien czas zamawiano dodatkową porcję „cukru melisu dla kanarków Księżnej Jejmości”229, a w pokojach kanclerzyny ustawiano „koszyki okrągłe, plecione, malowane z rączkami, dla kanarków”230. Annę Katarzynę wyraźnie cieszyła obecność latających stworzeń w prywatnych wnętrzach, stąd też wyrażała niezadowolenie, gdy inni zapominali o jej upodobaniach. Z nieukrywanym wyrzutem pisała w marcu 1739 r. do swej córki, kanclerzyny litewskiej Konstancji Franciszki z Radziwiłłów Sapieżyny (†1756): „bardzoś mi się zapomniała prędko, coś mi obiecała, to jest kanarków przysłać”231. Radziwiłłowa trzymała u siebie też inne ptaki — papugę, która mieszkała w okrągłej klatce z mosiężnego drutu ${ }^{232}$ oraz kruka, dla którego wykonano specjalną żelazną konstrukcję do siedzenia ${ }^{233}$. Zwierzęta te kupowano zagranicą, na osobiste jej polecenie. W 1735 r. w liście skierowanym do Michała Kazimierza sugerowała, że w Mannheim można nabyć „bestyjki różne, jako to papugi, kruki etc., czego tam jest pod dostatkiem, trzeba było nakupować i dać na okręty”234. Kanclerzyna z wyraźnym rozrzewnieniem dodawała „wiesz, że to jedyne moje ukontentowanie. Bardzoś niegrzeczny Rybeczko, żeś się sam tego nie domyślił”235.

O rozrywkach mieszkańców dworu w Białej świadczą też regularne zamówienia na kule i śrut „do strzelania zwierzyny”, głównie na potrzeby Hieronima Floriana ${ }^{236}$, a także „proch

222 AGAD, AR, dz. XXIX, rkps 29, s. 100.

223 AGAD, AR IV, nr 627, „Anna Katarzyna z Sanguszków Radziwiłłowa do Hieronima Floriana Radziwiłła, Biała, 13 I 1740”, s. 221.

224 AGAD, AR IV, nr 627, „Anna Katarzyna z Sanguszków Radziwiłłowa do Hieronima Floriana Radziwiłła, Biała, 13 I 1740”, s. 221. Kanclerzyna obawiała się też, że ciężkiej zimy nie przetrwają inne zwierzęta trzymane na dworze, w tym bażanty, o które zatroszczono się, „aby nie pozdychały”, AGAD, AR IV, nr 627, „Anna Katarzyna z Sanguszków Radziwiłłowa do Michała Kazimierza Radziwiłła, Biała, 16 I 1740”, s. 222.

225 W innym miejscu wzmiankowano o utrzymywaniu przez księżną pieska „Bobasia”, AGAD, AR, dz. XXIX, rkps 29, s. 216.

${ }^{226}$ AGAD, AR, dz. XXIX, rkps 29, s. 64.

227 AGAD, AR, dz. XXIX, rkps 29, s. 245.

228 AGAD, AR, dz. XXIX, rkps 29, s. 44.

229 AGAD, AR, dz. XXIX, rkps 29, s. 85.

230 AGAD, AR, dz. XXIX, rkps 29, s. 124.

231 AGAD, AR IV, nr 627, „Anna Katarzyna z Sanguszków Radziwiłłowa do Konstancji Franciszki z Radziwiłów Sapieżyny, Biała, 6 III 1739”, s. 57.

${ }^{232}$ AGAD, AR, dz. XXIX, rkps 29, s. 152.

233 AGAD, AR, dz. XXIX, rkps 29, s. 163.

234 AGAD, AR IV, nr 624, „Anna Katarzyna z Sanguszków Radziwiłłowa do Michała Kazimierza Radziwiłła, Biała, 29 VI 1735”, s. 193.

235 AGAD, AR IV, nr 624, „Anna Katarzyna z Sanguszków Radziwiłłowa do Michała Kazimierza Radziwiłła, Biała, 29 VI 1735”, s. 193.

${ }^{236}$ AGAD, AR, dz. XXIX, rkps 29, s. 140. 
leszczyński”237, również w tym samym celu ${ }^{238}$. Czas umilały też rozgrywki w bilard. Stół do tej gry utrzymywano w dobrym stanie; okazjonalnie został odświeżony i pomalowany wspomnianym wcześniej grynszpanem ${ }^{239}$.

Generalnie wiele interesujących przedmiotów, za które w badanym okresie zapłaciła Anna Katarzyna, trafiało do jej syna - Hieronima Floriana. Zamawiano dla niego różnorodne artykuły — od przesyłanych regularne, takich jak choćby puder ${ }^{240}$, po wysyłane sporadycznie, np. sepet $^{241}$ „,na suknie maszkaradne” wart 14 zł polskich ${ }^{242}$, bądź zapas płótna do wyklejenia pudła na strzelby ${ }^{243}$. Ze skarbu matki opłacano też produkty żywnościowe dla młodzieńca, nierzadko stanowiące zapas na miesiąc lub dwa, do tego towary „do zabrania z sobą na Litwę” lub pakowane na czas trwania sejmu. Na taki zestaw składały się zazwyczaj kosztowne cytrusy (pomarańcze i cytryny) i przyprawy (goździki, szafran, pieprz, cukier) ${ }^{244}$.

W prezentowanym studium pominięte zostały wzmianki dotyczące zakupów książek i utrzymania biblioteki należącej do Radziwiłłowej, gdyż ten aspekt został dokładnie omówiony w biografii opracowanej przez Wandę Karkucińską. W opracowaniu tym zamieszczono także pełen inwentarz księgozbioru kanclerzyny. Analizowane obecnie dokumenty nie stanowią tu żadnego ważnego uzupełnienia. Warto jedynie wspomnieć, że w ostatnich latach życia Anna Katarzyna zaczęła sukcesywnie porządkować tę obszerną kolekcję. Wiele dzieł zdecydowała się przekazać dzieciom. W 1741 r. napisała do swego syna, Michała Kazimierza: „rozkaż moje dziecię w bibliotece swojej uczynić miejsce na bibliotekę francuską, którą wkrótce stąd dla ciebie wybrawszy poślę chcąc, żebyście między sobą moje dzieci po śmierci mojej żadnej nie mieli kłótni”245.

Zachowany i przeanalizowany tu materiał źródłowy ukazuje Annę Katarzynę z Sanguszków Radziwiłłową jako magnatkę nie tylko dobrze sytuowaną, ale też przedsiębiorczą, z rozwagą podchodzącą do spraw majątkowych. Choć kanclerzyna niewątpliwie lubiła otaczać się przedmiotami modnymi i dobrymi jakościowo, racjonalnie rozdzielała środki na ich zakup. Kanclerzyna nie była skłonna wydawać kroci na najmodniejsze towary, wielokrotnie poddając w wątpliwość zasadność czynienia tego rodzaju wydatków. Zamiast tego lubowała się w rzeczach ładnych, choć nie szczególnie unikatowych i drogich. Pozyskiwanie na dwór rzeczy, z których korzystała, nadzorowała osobiście. Księżna miała przy tym sprecyzowane upodobania względem spożywanych potraw, serwowanego wina, rozrywek dworskich i przedmiotów użytkowych, ustawianych w jej prywatnych pokojach. Chętnie zlecała wykonanie wielu sprzętów rodzimym rzemieślnikom. Dbała jednak, aby korzystali ze wzorników, by przygotowane mobilia nie ustępowały aktualnej modzie i najchętniej odpowiadały zagranicznym wyrobom. Widoczne jest też rozsądne gospodarowanie zgromadzonymi dobrami, stąd w wielu przypadkach używane wcześniej przedmioty wykorzystywano ponownie, reperując je bądź przekształcając w nowe. Ciekawe są też wskazania co do zabawek przeznaczonych dla wnucząt kanclerzyny. Wzorowa-

237 Proch leszczyński — potoczna nazwa prochu wyrabianego w Lesznie.

238 AGAD, AR, dz. XXIX, rkps 29, s. 141.

239 AGAD, AR, dz. XXIX, rkps 29, s. 142.

240 AGAD, AR, dz. XXIX, rkps 29, s. 82, co ciekawe, w żadnym z wpisów nie pojawił się puder dla samej kanclerzyny. Wszystkie zakupione partie były wysyłane dla innych osób.

241 Sepet — skrzynia z szufladami, służąca do przechowywania drobnych przedmiotów.

242 AGAD, AR, dz. XXIX, rkps 29, s. 30.

243 AGAD, AR, dz. XXIX, rkps 29, s. 37

244 AGAD, AR, dz. XXIX, rkps 29, s. 36.

245 AGAD, AR IV, nr 629, „Anna Katarzyna z Sanguszków Radziwiłłowa do Michała Kazimierza Radziwiłła, Biała, 28 X 1741”, s. 48-49. 
ne na przedmiotach powszechnych na magnackim dworze miały prezentować świat w miniaturze, odzwierciedlając panujące zwyczaje i rozrywki.

Opisywane rejestry z Białej stanowią więc cenne źródło do poznania dworskiej codzienności w XVIII stuleciu, a także wartościowy materiał do badań wielu zagadnień z ówczesnej sfery materialnej.

Adres Autorki:

dr Anna Penkała-Jastrzębska

Instytut Historii i Archiwistyki

Uniwersytet Pedagogiczny

im. Komisji Edukacji Narodowej w Krakowie

ul. Podchorążych 2

30-084 Kraków

anna.penkala-jastrzebska@up.krakow.pl

https://orcid.org/0000-0001-6386-8139

\section{BIBLIOGRAFIA}

\section{Źródła archiwalne}

AGAD [Archiwum Główne Akt Dawnych w Warszawie], AR [Archiwum Warszawskie Radziwiłłów], dz. [dział] IV, rkps [rękopis] nr 623, 624, 627, 628, 629, 630.

AGAD [Archiwum Główne Akt Dawnych w Warszawie], AR [Archiwum Warszawskie Radziwiłłów], dz. [dział] V, rkps [rękopis] nr 13898/III, 13898/V.

AGAD [Archiwum Główne Akt Dawnych w Warszawie], AR [Archiwum Warszawskie Radziwiłłów], dz. [dział] XXIX, rkps [rękopis] nr 29.

\section{Źródła i opracowania publikowane}

Listy Magdaleny z Czapskich. 2016. „Gdybym Cię, moje Serce, za męża nie miała, żyć bym nie mogła”. Listy Magdaleny z Czapskich do Hieronima Floriana Radziwiłła z lat 1744-1759, wstęp i oprac. I. Maciejewska, K. Zawilska, Olsztyn.

Anusik Zbigniew, Stroynowski Andrzej. 1989. Radziwiłlowie w epoce saskiej. Zarys dziejów politycznych i majątkowych, „Acta Universitatis Lodziensis. Folia Historica”, nr 33, s. 29-58.

Codzienne kłopoty. 2013. Codzienne kłopoty, wielkie interesy i podwójna elekcja. Korespondencja radziwiłłowskich urzędników z księżną Anna z Sanguszków Radziwiłłowa i jej synem Michałem Kazimierzem z 1733/1734 roku, wyd. J. Dygdała, Warszawa.

Dumanowski Jarosław. 2006. Świat rzeczy szlachty wielkopolskiej w XVIII wieku, Torun.

Dymnicka-Wołoszyńska Hanna. 1980. Radziwiłł Hieronim Florian, [w:] Polski Słownik Biograficzny, red. E. Rostworowski, t. 30, Wrocław, s. 185-188.

Dymnicka-Wołoszyńska Hanna. 1987. Radziwiłt Michat Kazimierz zw. Rybeńko (1702-1762), [w:] Polski Słownik Biograficzny, red. E. Rostworowski, t. 30, Wrocław, s. 299-306.

Gloger Zygmunt. 1902. Encyklopedia staropolska ilustrowana, t. III, Warszawa.

Inwentarz pośmiertny. 2016. Inwentarz pośmiertny Jana Karola Mniszcha spisany po 19 września 1759, Lwowska Narodowa Naukowa Biblioteka Ukrainy im. Wasyla Stefanyka, f. 141 (Zbiór Aleksandra Czołowskiego), rkps 120, s. 1-26 (LNBU, 141-1-120), [w:] Pałac w Wiśniowcu w świetle inwentarzy staropolskich, oprac. A. Betlej, A. Dworzak, A. Markiewicz, Kraków 2016, s. 51-75.

Jakuboszczak Agnieszka. 2008. Sarmacka dama Barbara Sanguszkowa (1718-1791) i jej salon towarzyski, Poznań.

Jasielczuk Leszek. 2005. Dzieje klasztoru ojców dominikanów w Klimówce 1682-1832, Białystok. 
Kabacińska Katarzyna. 2010. Od grzechotki do... — słów kilka o zabawkach dziecięcych, „Studia Edukacyjne”, nr 11, s. 125-138.

Karkucińska Wanda. 2000. Anna z Sanguszków Radziwilłowa (1676-1747). Działalność gospodarcza i mecenat, Warszawa.

Kicińska Urszula. 2017. Splendory domowe w staropolskich inwentarzach ruchomości, „Kwartalnik Historii Kultury Materialnej”, R. LXV, nr 4, s. 461-470.

Kitowicz Jędrzej. 2003. Opis obyczajów za panowania Augusta III, oprac. R. Pollak, Wrocław.

Kowecka Elżbieta. 1983. Historia manufaktur i fabryk porcelany w Polsce, [w:] Polska porcelana, red. E. Kowecka i in., Wrocław-Warszawa-Kraków, s. 12-62.

Krótki Zuzanna. 2016. Alkohol w leksyce staro- i średniopolskiej, „Prace Językoznawcze”, nr 18/2, s. $83-100$.

Kuras Katarzyna. 2018. Dwór królowej Marii Leszczyńskiej. Ludzie, pieniądze, wpływy, Kraków.

Lesiński Jerzy. 1996. Spory o dobra neuburskie, „Miscellanea Historico-Archivistica”, t. 6, s. $95-132$.

Maciejewska Iwona, Zawilska Katarzyna. 2015. „Białogłowy dokazuja, czego chca”, czyli o sztuce przekonywania i pochlebstwa (listy Konstancji i Magdaleny Czapskich do Hieronima Floriana Radziwiłła), [w:] Kobieta i mężczyzna. Jedna przestrzeń - dwa światy, red. B. Popiołek, A. Chłosta-Sikorska, M. Gadocha, Warszawa, s. 263-271.

Markuszewska Aneta. 2012. Festa i muzyka na dworze Marii Kazimiery Sobieskiej w Rzymie (1699-1714), Warszawa.

Penkała Anna. 2016. Panieńskie ochędóstwo. Kwestie posagowe i wienne w małzeństwach szlachty województwa krakowskiego w czasach saskich, Kraków.

Penkała-Jastrzębska Anna. 2019. Macierzyństwo w świetle korespondencji Karoliny Teresy z Radziwiłłów Jabłonowskiej do matki Anny z Sanguszków Radziwiłłowej, „Horyzonty Wychowania”, t. 18 , nr 45, s. 69-82.

Penkała-Jastrzębska Anna. 2020. Mit srebrnej łyżeczki? Przedmioty prestiżowe w szlacheckich inwentarzach majątkowych z ksiag grodzkich województwa krakowskiego w czasach saskich, „Kwartalnik Historyczny”, t. CXXVII, nr 1, s. 33-62.

Penkała-Jastrzębska Anna. 2021. Stużba na kobiecym dworze magnackim. Przyczynek do analizy zagadnienia w świetle rejestrów dworskich Anny Katarzyny z Sanguszków Radziwiłłowej, [w:] Dwór kobiecy w Rzeczpospolitej XVII i XVIII wieku, red. B. Popiołek, A. Penkała-Jastrzębska, K. Pyzla, Kraków, s. 155-176.

Pietrzak Jarosław. 2016. Dziedzic królewskiej purpury. Słowo i obraz w propagandowych działaniach Michała Kazimierza Radziwiłła „Rybeńki”, „Zeszyty Naukowe Towarzystwa Doktorantów Uniwersytetu Jagiellońskiego. Nauki Społeczne”, nr 14 (3), s. 99-131.

Popiołek Bożena. 2020. Dobrodziejki i klienci. Specyfika patronatu kobiecego i relacji klientalnych w czasach saskich, Warszawa.

Przyrembel Zygmunt. 1927. Historia cukrownictwa w Polsce, Warszawa.

Przyrembel Zygmunt. 1936. Farfurnie polskie dawne i dzisiejsze, Lwów.

Roćko Agata. 2013. Sarmacki świat wartości materialnych w XVIII wieku. Zarys problematyki, [w:] Codzienność i niecodzienność oświeconych, t. 1: Przyjemności, pasje i upodobania, red. B. Mazurkowa, Katowice, s. 11-24.

Ryś Jan. 2010. Zabawki militarne w okresie staropolskim, [w:] Dawne i współczesne zabawki dziecięce, red. D. Żołądź-Strzelczyk, K. Kabacińska, Poznań, s. 137-147.

Skrzypietz Aleksandra. 2013. Hieronim Florian Radziwiłt w zalotach, [w:] Codzienność i niecodzienność oświeconych, cz. 2: W rezydencji, w podróży i na scenie publicznej, red. B. Mazurkowa, Katowice, s. 101-114.

Słaby Agnieszka. 2014. Rządzicha oleszycka. Dwór Elżbiety z Lubomirskich Sieniawskiej jako przykład patronatu kobiecego w czasach saskich, Kraków.

Targosz Karolina. 1975. Uczony dwór Ludwiki Marii Gonzagi (1646-1667). Z dziejów polsko-francuskich stosunków naukowych, Wrocław. 
Targosz Karolina. 1997. Sawantki w Polsce XVII w. Aspiracje intelektualne kobiet ze środowisk dworskich, Warszawa.

Tomczak Lucyna. 2001. Ludowe nazwy ziemniaków i ich odmian, „Acta Universitatis Wratislaviensis”, t. 16, nr 2282, s. 123-129.

Trzeciecki Maciej. 2017. Naczynia gliniane z XVII-XVIII wieku, z badań zespołu podworskiego w Niegowie pod Wyszkowem. Przyczynek do poziomu życia szlacheckiej prowincji, „Kwartalnik Historii Kultury Materialnej”, R. LXV, nr 2, s. 169-187.

Zielińska Teresa. 1989. Więź rodowa domu radziwiłłowskiego w świetle diariusza Michała Kazimierza Radziwiłła „Rybeńki”, „Miscellanea Historico-Archivistica”, t. 3, s. 175-190.

Zuba Krzysztof. 2002. Michat Kazimierz Radziwitt. (1702-1762) — portret psychofizyczny, „Medycyna Nowożytna”, nr 9/1-2, s. 53-84.

Żołądź-Strzelczyk Dorota. 2013. „A cacek też dużo było”: zabawki dziecięce na ziemiach polskich w średniowieczu i w epoce nowożytnej, „Kwartalnik Historyczny”, t. CXX, nr 1, s. 5-30.

The material culture of a magnate court illustrated with the property inventories of Anna Katarzyna Radziwiłł née Sanguszko from the years 1738-1741

The article presents the functioning of the court of Anna Katarzyna Radziwiłł née Sanguszko in the Biała estate, with a special focus on the artefacts used by the household. An analysis of property inventories and correspondence from 1738-1741 disclosed the rhythm of the court's functioning, especially a distinction between everyday matters and varied manifestations of lavishness and luxury. Anna Katarzyna Radziwiłł’s activity in that sphere is particularly interesting as after her husband's death she had a huge fortune at her disposal and she controlled both the political and the economic undertakings of the Radziwiłł family. Her actions are documented by vast sources, which greatly extend the scope of research on the courts of female magnates in the 18th c.

Translated by Izabela Szymańska 